\title{
IMPACT OF THE ŁÓDŹ AGGLOMERATION ON WATER QUALITY INDICATORS AND LOAD OF POLLUTANTS IN NER AND WARTA RIVERS, IN THE PERIOD 1995-2011
}

\author{
Józef Mosiej ${ }^{\bowtie}$,Jan Skrzypski, Teresa Suchecka \\ Institute of Environmental Engineering, Faculty of Civil and Environmental Engineering, Warsaw University of Life \\ Sciences-SGGW, Nowoursynowska 161/33, 02-787 Warszawa
}

\begin{abstract}
Aim of the study

The aim of the work is to assess the impact of pollution discharge limitation after the modernization of the LAM sewage treatment plant on pollutant loads in the middle section and downriver of the Ner river. In order to do this, pollutant concentrations and loads were compared in two periods: 1995-2003 and 2004-2011.
\end{abstract}

\section{Material and methods}

The sources of data included information obtained from wastewater treatment plant regarding the basic indicators of pollutants discharged to the river, as well as flows and concentrations of pollutants in the cross-sections of Ner and Warta rivers.

As an indicator, we adopted the share of pollutants introduced into the Warta river by the Ner river in the pollution load of the Warta river in the first measurement cross-section on the Warta below the confluence with the Ner river.

\section{Results and conclusions}

In the period 1995-2003, the average annual flow of the Ner river was about $10 \%$ of the average annual flow of the Warta river below the confluence with the Ner river (Koło cross-section), and in the period 2004-2011, it remained at a similar level i.e. 13.8\%, whereas the load of pollution brought in by Ner amounted to, on average: $27 \%$ nitrogen, $37 \%$ total phosphorus, $39 \% \mathrm{BOD}_{5}$ and $28 \%$ total suspended solids in the water of Warta river; whereas in the second period, the figures were $27.9 \%, 42.6 \%, 19.8 \%$ and $19.6 \%$ respectively.

As in the first period, the lack of adequate impact was found of the decrease in the phosphorus discharged by the wastewater treatment plant on its content in the water of Ner river; on the other hand, the decrease of the $\mathrm{BOD}_{5}$ index and total suspension ratio was recorded. In conditions of low phosphorus concentration in the discharged sewage (below $4 \mathrm{~g} \cdot \mathrm{m}^{-3}$ ) in 2007 it reached a maximum of $1.23 \mathrm{~g} \cdot \mathrm{m}^{-3}$ discharged from the sewage treatment plant, and at the confluence with the Ner River, no improvement in water quality in the Chełmno profile was observed (average annual concentration $0.78 \mathrm{~g} \cdot \mathrm{m}^{-3}$ ).

Keywords: water quality, wastewater treatment, Ner river 


\section{INTRODUCTION}

The environmental protection, including the protection of aquatic environment, in qualitative terms should consist in limiting the emission of pollutants into the environment on the one hand, and on the other hand, improving the environment's ability to assimilate pollution, i.e. deploying natural processes occurring in the environment to utilize pollution. In the case of the aquatic environment, an important condition for improving water quality is to trigger the natural self-purification processes of the aquatic environment. The importance of this process can be demonstrated by the fact that despite the construction over the last 30 years of many wastewater treatment plants, which dramatically reduced the discharge of untreated wastewater into the environment, there is no radical improvement in the quality of water in our rivers. The main obstacle is the limited process of self-purification of watercourses and water bodies, mainly due to the loss of natural quality of many rivers, both due to the destruction of biological life in rivers caused by excessive discharge of untreated sewage in the past, as well as the loss of natural quality of caused by regulation of rivers for economic needs (Bednarczyk, 1997).

High costs of biological wastewater treatment, and even higher costs of removing biogenic pollutants contained in the waters flowing from the treatment plant, induce engineers to look for alternative ways of wastewater treatment and water purification. At the same time, the currently operating two-stage (mechanical and biological) wastewater treatment systems in many cases do not meet the requirements for the concentration of pollutants at the output. In many cases, the construction of traditional cleaning systems (III stage of purification - reduction of biogenic compounds) may prove too expensive. Therefore, it is likely that unconventional water purification systems will become increasingly popular. Unfortunately, these systems require relatively large areas, because the purification processes they support are highly dependent on the active surface.

The subject of the work is in line with current EU legislation regarding new regulations that are intended to stimulate and facilitate the re-use of water for agricultural irrigation in the countries belonging to the
European Community. The new regulations will help farmers make the best use of treated wastewater for irrigation, which will also contribute to reducing water shortage in agriculture, and to protecting the aquatic environment.

In the present study, we made an attempt to assess changes in water quality in the Ner river in the years 1995-2011. The Ner river, due to the scale of degradation, is a good observation object for changes related to self-purification processes of aquatic ecosystems. Many rivers in Europe have lost their self-cleaning capacity due to strong industry pressure in the 1970s and the lack of effective wastewater treatment systems. Improving the self-cleaning potential of watercourses begins with reducing the pressure associated with emissions of pollutants. In the case of the Ner river, the quality of water in period 1995-2004 depended on the effectiveness of wastewater treatment at the Group Wastewater Treatment Plant (GOŚ) in Łódź, which received both municipal and industrial wastewater. Discharged wastewater, mechanically treated, contributed to the increase of oxygen indexes values (BOD and $\mathrm{COD}$ ). At the measurement points on the New river, below the discharge from the treatment plant, the values of these indicators in the discussed period were even 10 times higher than before the discharge. Also, the concentrations of nitrogen and phosphorus compounds in the cross-sections of the river before and after the discharge from the treatment plant indicate their lower content in upriver sections, not covered by the emission of pollutants from the GOŚ (Mosiej et al., 2007a; Mosiej et al., 2007b; Multan 1993).

The goal of the present work is:

1) To assess the impact of the discharge of treated sewage from the modernized sewage treatment plant of Łódź Municipal Agglomeration ( on pollution loads in the middle and lower course of the Ner river. The study compares the concentrations and loads of pollutants before the modernization of the treatment plant, i.e. in 1995-2003 , and after the modernization, in the years 2004-2011.

2) To assess the share of pollutant loads flowing from the Ner river catchment on the quality of water in the Warta river. 


\section{DESCRIPTION AND PARTICULAR CHARACTERISTICS OF THE STUDY AREA}

The specific natural system of the Łódź Municipal Agglomeration (watershed location, limited water resources, lack of larger natural watercourses), along with the development of the city, resulted in the creation of a specific system connecting the city and the agglomeration with the water supply system and the sewage disposal system. Water management in the region has undergone dynamic changes and transformations as the city and the entire agglomeration developed. This was reflected in the restrictions on the use of local groundwater, and the transfer of water from the Pilica river; changing concepts of agglomeration water supplay construction of a sewage treatment plant for a part of the Łódź Municipal Agglomeration (LAM); reconstruction of the technical system of irrigation in the valley; as well as changes in agricultural production technologies on farms using valley areas. Further changes were enforced by legislative conditions regarding water management and environmental protection. The results of scientific research and their implementation for a more complete sewage treatment and achieving good water status in the Ner river were also of great importance (Banaszkiewicz, 2002, Ilnicki et al., 2003; Jaskuła et al., 2016; Mosiej and Multan, 1998; Multan, 1996; Somorowski et. al., 1991; Zamojski, 1995).

The Ner is a lowland river of grade III, one of the larger right-bank tributaries of the middle course of Warta river. In the current administrative division of Poland, Ner runs though Wysoczyzna Łaska (upland) in Łódź region (voivodeship), and through Kotlina Kolska (valley) in Wielkopolska region (voivodeship). The Ner river flows out near Wiśniowa Góra at an altitude of $215 \mathrm{~m}$ above sea level, and flows into Warta river at $444.4 \mathrm{~km}$ of its course near the village of Majdany in the Koło district (poviat), at an altitude of about $94 \mathrm{~m}$ above sea level. In the upper course, the river has a significant slope, amounting to approx. $3 \%$. The total length of Ner is $125.9 \mathrm{~km}$, while the catchment area is $1835 \mathrm{~km}^{2}$, which is about $3.5 \%$ of the Warta river catchment. Within the borders of Łódź region, the average flow is about $6 \mathrm{~m}^{3} \cdot \mathrm{sec}^{-1}$, and slightly above the confluence to the Warta river, it is about $10 \mathrm{~m}^{3} \cdot \mathrm{sec}^{1}$. The average width of the river in the middle course is $18 \mathrm{~m}$, while its average depth is $1.2 \mathrm{~m}$ with observed fluctua- tions from 0.5 to $1.9 \mathrm{~m}$. The average water velocity in the riverbed is about $0.5 \mathrm{~m} \cdot \mathrm{sec}^{-1} \mathrm{~s}$. The maximum range of water level fluctuations in the lower part is $3.5 \mathrm{~m}$. Rainwater drainage systems from cities and, above all, from Łódź contribute to rapid changes in the river water level. Rainwater runoff (i.e. storm water) occurring in the Łódź agglomeration is a frequent cause of floods in the valley of the Ner river (Skrzypski, 2013).

In the lower section of the Ner river running through the Wielkopolska region (section 0-19+930 above the confluence with the Warta river) in 2007-2008 repair and adjustment works were carried out on the longitudinal and transverse section of the riverbed. The result of these works was the removal of bottom sediments, increasing the capacity of the riverbed, and thus limiting flooding. Measurements and calculations showed that over 20 years silting of the confluence section occurred, in some places reaching up to $1.5 \mathrm{~m}$, which understandably caused a gradual increase in the ordinate of the water table, especially in the zone of low and medium flows. The silting was caused not only by the discharge of untreated sewage to Ner river in the past, but also by regulatory work in the upper and middle course of the river, which caused accelerated erosion and deposition of its products in the estuary. The material selected from the riverbed was deposited on the floodplain terrace, hardened and sown with grass. The riverbed was rebuilt along its entire width while maintaining the natural gradient of the slopes.

River regulation and removal of silt from the bottom of the river has a significant impact on its condition and ecological potential. Considering the fact that sewage discharges from the Łódź agglomeration were the source of silting, their removal outside the riverbed definitely contributed to improving the quality of water in the Ner river in the Chelmno cross-section at the confluence to the Warta river. However, the deepening of the Ner riverbed caused a lowering of the water level during the spring flooding of the valley, and thus initiated the process of draining swamps as well as accelerating the outflow of water from meadows, and forcing earlier haymaking. Ultimately, this can lead to adverse changes that reduce the surface area of wetland habitats, and the biodiversity of the organisms that inhabit them (Skrzypski, 2013).

Arable lands are the major land use form in the catchment, constituting $63.5 \%$, whereas forests amount 
to $14.2 \%$, and permanent grassland, to $10.8 \%$. Urban areas account for $11.4 \%$ of the area, also including the cities of Łódź, Konstantynów Łódzki and Pabianice, in the upper reaches of Ner river.

In the Ner river valley there are 17 weirs, accumulating the water by using gravity irrigation damming. The then Regional Board of Land Reclamation and Water Facilities (currently the National Water Management Authority) leased 11 dams located on the Ner river to private investors for use in electricity generation. In the case of the use of damming structures for the production of electricity, the manner of operation differs from the method of draining the river valley, assumed in drainage improvement plan in which the river's water was only meant for irrigation of meadows (Lik and Sołtuniak, 2012). When collecting water for irrigation of meadows, weirs were closed for several days during irrigation (in total, about 25-30 days a year during the vegetation period). This method of exploitation for energy purposes did not hinder the movement of bottom sediments or migration of ichthyofauna. On the other hand, in the use linked to energy generation, weirs accumulate water continuously (in exceptional cases, in order not to damage the weir structure, they are opened for several hours during the ice floe flow during spring thaws). In this case, above the hyrotechnical device, a section is formed where bottom sediments are stopped, in which processes of decomposition of organic matter under anaerobic conditions may occur, unfavourable from the point of view of ichthyofauna protection. In general, building up the river with damming structures significantly hinders the existence and migration of fish, but at the same time, it can facilitate oxygen diffusion, which stimulates the river's self-purification processes. The monitoring of ichthyofauna in 2000-2005 showed 10 species of fish at the beginning of the study period, and the increase in that number in subsequent years to 21 . Nevertheless, ichthyofauna in the Ner river is relatively poor compared to other rivers of similar size (Ambrozik, 2010; Śliwińska, 2009; Penczak, 2010).

\section{METHODOLOGY OF RESEARCH AND RESULTS ANALYSIS}

Source material consisted of data obtained from:

- Group Sewage Treatment Plant (GOŚ) of the Łódź Municipal Agglomeration (LAM), regarding the amount and quality of sewage inflowing to and leaving the GOŚ,

- Regional Inspectorates for Environmental Protection (WIOŚ) in Łódź and Poznań, regarding 5 measurement and control points (ppk) on the Ner river: before the discharge of sewage in Smulsko, directly after discharge from GOŚ, Lutomiersk, Dąbie, and Chełmno (located directly before the confluence to Warta river). On the Warta river, 2 ppk points were taken into account: Wilamów before the Ner river entering the Warta river, and Koło downriver from it (see: Fig. 1).

- Institute of Meteorology and Water Management, Poznań Branch - water flow rate in water gauge cross-sections.

In order to assess changes in the quality of Ner river waters in the years 1999-2011 on the section from the GOS to the estuary, the values of selected pollution indicators in wastewater discharged from sewage treatment plant were compared to those in river water at the Chełmno cross-section. When determining the impact of Ner river on the quality of Warta river waters, total nitrogen, total phosphorus, biochemical oxygen demand $\left(\mathrm{BOD}_{5}\right)$ and total suspended solids were taken into account. These indicators are systematically analysed by the Regional Inspectorates for Environmental Protection (WIOŚ). The loads of introduced pollutants were calculated on the basis of their concentration values and water flow volume in the cross-sections of Wilamów and Koło on the Warta river, and Chełmno cross-section on the Ner river (see: Fig. 1). The average annual pollution load was calculated as the product of the average annual flow in the given measurement cross-section, and the average annual concentration of a given pollution index. The study uses the results of observations and measurements of pollution published by the Regional Inspectorates of Environmental Protection in Lódź and Poznań. The average annual flows from 1999-2011 were calculated by the Institute of Meteorology and Water Management, Poznań Branch: for the Chełmno profile (on the Ner river) - based on flows for the Dabie water gauge, and for the town of Wilamów (on the Warta river) - based on flows for the Uniejów water gauge, and for the town of Koło (on the Warta river) - based on flows for the water gauges of Dąbie and Uniejów. 


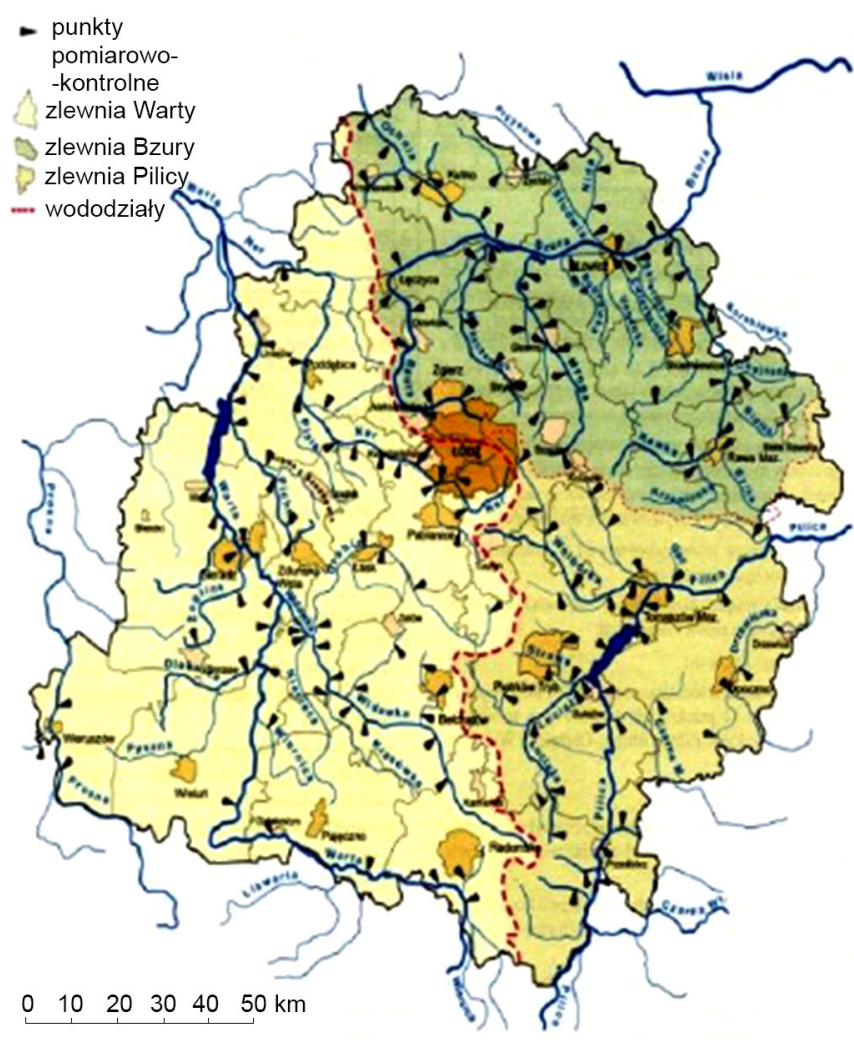

A

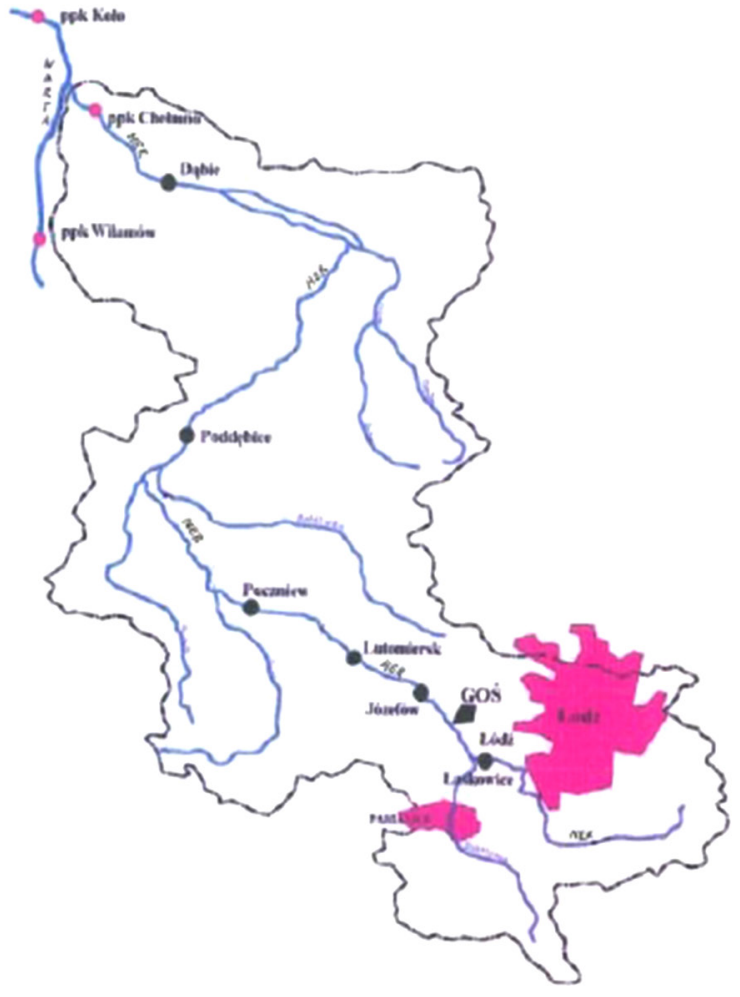

B

Fig. 1. Map of the Warta river catchment with Ner tributary (A) and detail map of Ner river (B) catchment with marked measurement points

In the years covered by the analysis, two periods were distinguished, corresponding to the subsequent stages of the GOŚ's operation: the years 1999-2003 the start-up period of the biological part, and the years 2004-2011 - the full operational efficiency of the biological part.

The research covered the Ner river at 5 measuring points: before the discharge of sewage in the town of Smulsko, directly after discharge from the GOŚ, then in Lutomiersk, as well as in Dąbie and Chełmno located just before the confluence with the Warta river. On the Warta river, 2 measuring points were taken into account: one in Uniejów located before the confluence of the Ner river and Warta river, and the other in Koło, behind the confluence. The data derives from two research periods: 1995-2003 and 2004-2011, which is before and after modernization of the treatment plant. An analysis of selected water quality indicators was carried out: $\mathrm{BOD}_{5}$, total suspended solids, total and ni- trate nitrogen as well as total and phosphate phosphorus. For the period of 1999-2003, the results contained in previously published materials were used (Mosiej et al., 2007b, Mosiej and Suchecka, 2017).

\section{RESULTS}

Data analysis indicates that a significant decrease in the COD value in the water of Ner river did not occur until after 2005, and this is related to the reduction of the amount of industrial wastewater and the reduction of the amount of wastewater discharged from the $\mathrm{LAM}$ area. The amount of industrial wastewater flowing into the GOS in 2011 was 2 times lower than in 1989. At the same time, the modernization of biological treatment technology has allowed the BOD index to be reduced several-fold at the outflow from sewage treatment plants. The degree of reduction of nitrogen and total phosphorus in the sewage treatment plant in the years 
2004-2011 was $77 \%$ and $87 \%$, respectively, while maintaining their concentrations in treated wastewater in accordance with applicable standards (see: Table 1).

The data show a significant decrease in the share of nitrogen and phosphorus load from the treatment plant in the Ner river load in 2004-2011. Table 2 presents changes in the load of basic pollution indicators discharged from the treatment plant in two periods under comparison: (1995-2003) and (2004-2011).

In the period of 1999-2003, $\mathrm{BOD}_{5}$ loads were reduced 10-fold, total nitrogen $\left(\mathrm{N}_{\text {tot }}\right)$ was reduced more than 2-fold, total phosphorus $\left(\mathrm{P}_{\text {tot }}\right)$ was reduced 4-fold, and total suspension was reduced 6-fold. The reduction in the value of these indicators at the confluence to the Ner (Chelmno cross-section) in the discussed comparative period is much lower. In the years 2004-2011, the share of the load of pollutants from the sewage treatment plant in the total value of the load in the Chelmno section was: for $\mathrm{BOD}_{5}-43 \%, \mathrm{~N}_{\text {tot }}-$ $64 \%, \mathrm{P}_{\text {tot }}-57 \%$, and total suspended solids $-37 \%$. Relatively low flows in the river mean that despite maintaining the quality standards of discharged sewage, these loads still have a significant impact on the chemistry of the river.

Table 1. Concentrations of selected forms of nitrogen and phosphorus in the Ner river water, in four cross-sections, during the period 2004-2011 (Skrzypski, 2013).

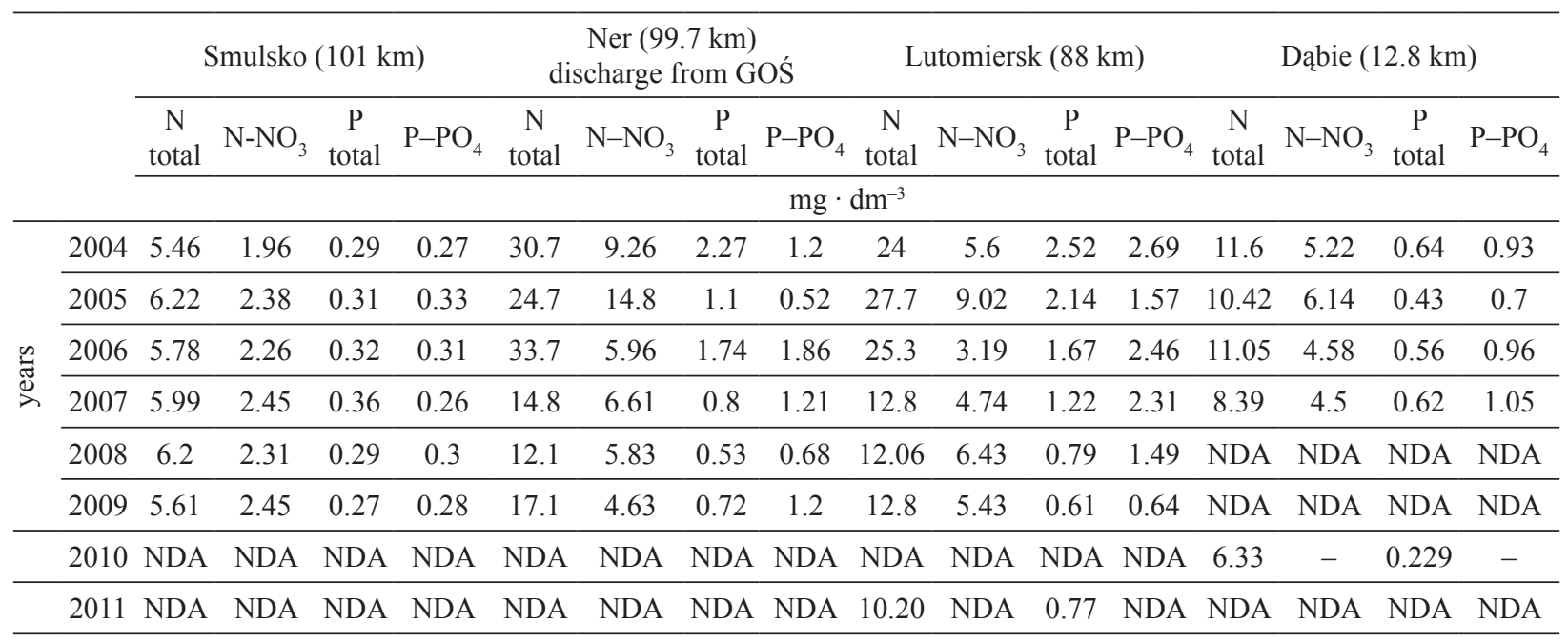

NDA - no data available

Table 2. Changes in the load of basic pollutants in selected cross-sections, in the periods: 1995-2003 and 2004-2011.

\begin{tabular}{lcccc}
\hline & $\begin{array}{c}\text { Load } \times 10^{6} \mathrm{~g} / \text { year } \\
\text { discharge from GOŚ } \\
\text { Łódź }\end{array}$ & $\begin{array}{c}\text { Load } \times 10^{6} \mathrm{~g} / \mathrm{year} \\
\text { Ner river (Chełmno } \\
\text { cross-section) }\end{array}$ \\
\hline $\begin{array}{l}\text { Pollution } \\
\text { index }\end{array}$ & $1995-2003$ & $2004-2011$ & $1995-2003$ & $2004-2011$ \\
\hline $\mathrm{BOD}_{5}$ & 5503 & 582 & 4196 & 1339 \\
\hline $\mathrm{N}_{\text {tot }}$ & 2506 & 1132 & 3237 & 1773 \\
\hline $\mathrm{P}_{\text {tot }}$ & 274 & 68 & 332 & 119 \\
\hline $\begin{array}{l}\text { TSS (total } \\
\text { suspended } \\
\text { solids) }\end{array}$ & 6549 & 1115 & 6939 & 3014 \\
\hline
\end{tabular}

The balance of pollutant load in the cross-section of the river below the discharge of sewage from the treatment plant and at the confluence with the Warta river indicates that about half of the volume of pollutant loads introduced into the Warta river comes from other sources. A potential source of the remainder of the pollution load could be emissions from bottom sediments, in which a significant proportion of organic compounds have been deposited in the years preceding the commissioning of the treatment plant, and their slow mineralization may still result in their concentrations increasing for many years (see: Table 2 and Fig. 2). 
The chemical parameters of water quality were significantly impacted by the devices raising the water level for irrigation (weirs, thresholds), which on the one hand can cause local deposition of suspensions, but on the other hand, they contribute to water aeration, thus stimulating self-purification processes of the river. The increase in the river's self-purification potential can be found by analysing the values of $\mathrm{BOD}_{5}$ indicators in 2004-2009 in the Lutomiersk - Poddębice - Chełmno cross-sections, which demonstrates that as the distance from the source of pollution increases, the values decrease in the down part river. The decrease in the $\mathrm{BOD}_{5}$ indicator is also evident over time (see: Fig. 3). To compare, the $\mathrm{BOD}_{5}$ load values before the discharge point from treatment plant remain stable throughout the period of 2004-2010.

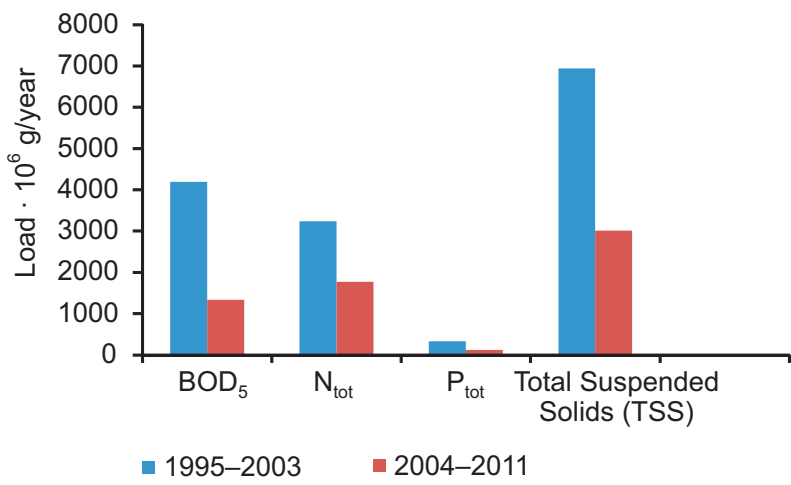

Fig. 2. Comparison of loads of selected pollution indicators at the Chełmno water-gauge cross-section, in the periods of 1995-2003 and 2004-2011 (average annual values)

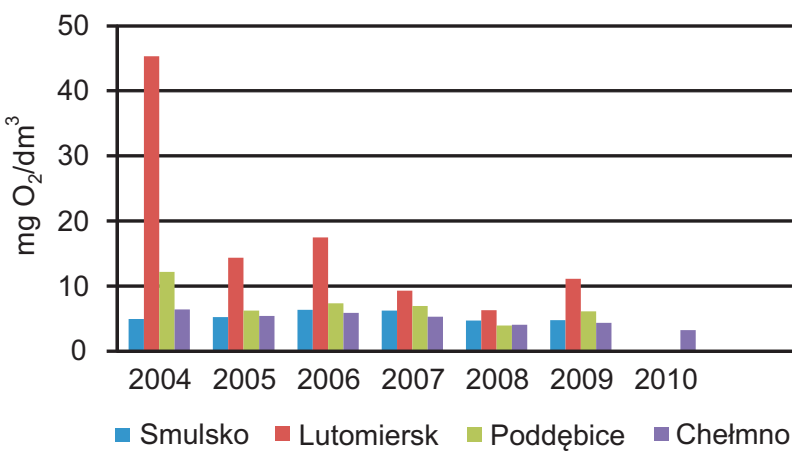

Fig. 3. Average annual values of $\mathrm{BOD}_{5}$ indicator: $\mathrm{mg} \mathrm{O}_{2} / \mathrm{dm}^{3}$ in the Ner river
Figure 4 presents the analysis of total and phosphate phosphorus concentrations in four selected cross-sections, in the years 2004-2009. For the Smulsko cross-section (before discharge from the GOŚ), the share of $\mathrm{PO}_{4}$ in $\mathrm{P}$ total remains at a similar level. In the Ner river cross-section past the discharge from the GOŚ, the $\mathrm{PO}_{4}$ share in $\mathrm{P}$ total has been increasing since 2006; similarly so in the cross-section of Lutomiersk. In the Dąbie section (just before the tributary to the Warta river) this tendency is already noticeable in 2004. The increase in the share of orthophosphates in total phosphorus was due to the modernization of the treatment plant (full biochemical decomposition of phosphorus organic compounds), but above all to the stimulation of self-purification processes in the river, which occur faster the farther away from the source of pollution.

Data on total nitrogen concentration indicate a decrease in concentration in the Lutomiersk and Dąbie cross-sections only in 2007 (see: Fig. 5). At the same time, the $\mathrm{N}_{\text {tot }}$ concentration in the Ner river cross-section after the discharge from GOŚ decreases, hence it can be associated with the improvement of the quality of discharged sewage. The share of nitrates $\left(\mathrm{N}-\mathrm{NO}_{3}\right)$ in total nitrogen $\left(\mathrm{N}_{\text {tot }}\right)$ remains on average at the level of $50 \%$ (see: Fig. 5 and 6 ).

The nitrate balance must also take into account the role of nitrates as an oxidant in the decomposition of organic matter. Under anoxic conditions, with such high $\mathrm{BOD}_{5}$ values, nitrates decomposed in the denitrification process to free nitrogen, hence the share of mineral forms of nitrogen in total nitrogen is only $50 \%$.

The $\mathrm{BOD}_{5}$ load values in the Chelmno section in 2004-2011 represent only $20 \%$ of their value in the years 1995-2003 (see: Table 2). On the basis of the quantitative data presented above (see: Fig.7), it can be stated that the share of pollution load brought by the Ner river to the Warta river in 2004-2011 decreased several times compared to the years 1995-2003 (see: Table 2). The share of $\mathrm{BOD}_{5}$ load consit $21 \%, \mathrm{~N}_{\text {tot }}$ $52 \%, \mathrm{P}_{\text {tot }}-27 \%$, and TSS $-30 \%$ load of pollutans in period 1995-2003. As it result from the table and charts, the values of these indicators also decreased for the cross-sections of Koło and Uniejów on the Warta river (see: Fig. 7 and 8).

In the cross-section of Chełmno (the lower section of the Ner river, $5 \mathrm{~km}$ before its confluence to the Warta 
Mosiej, J., Skrzypski, J., Suchecka, T. (2019). Impact of the Łódź Agglomeration on water quality indicators and load of pollutants in Ner and Warta rivers, in the period 1995-2011. Acta Sci. Pol., Formatio Circumiectus, 18 (4), 25-35. DOI:
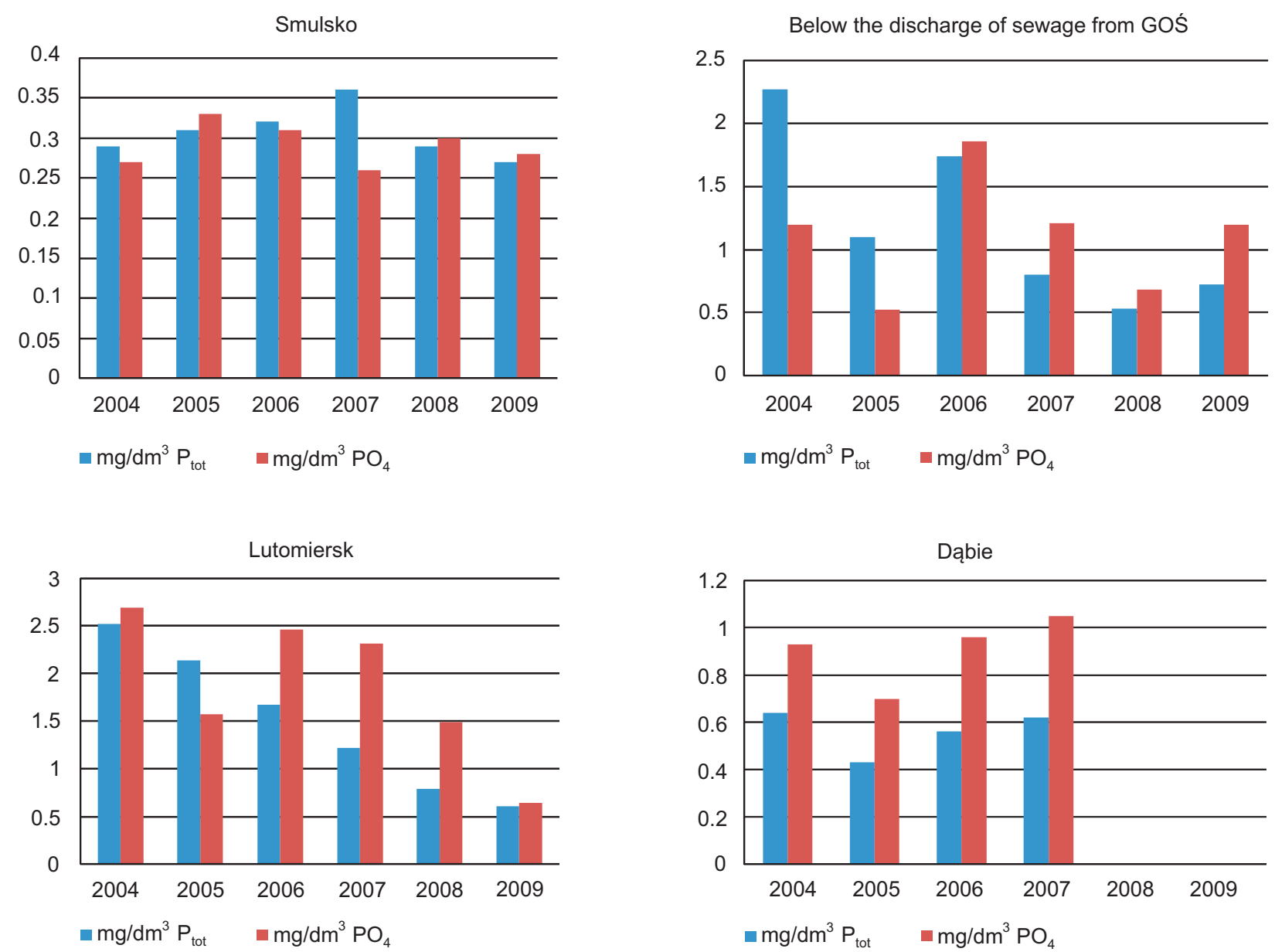

Fig. 4. Changes in the concentration of total and phosphate phosphorus in 4 measurement points (average annual values)

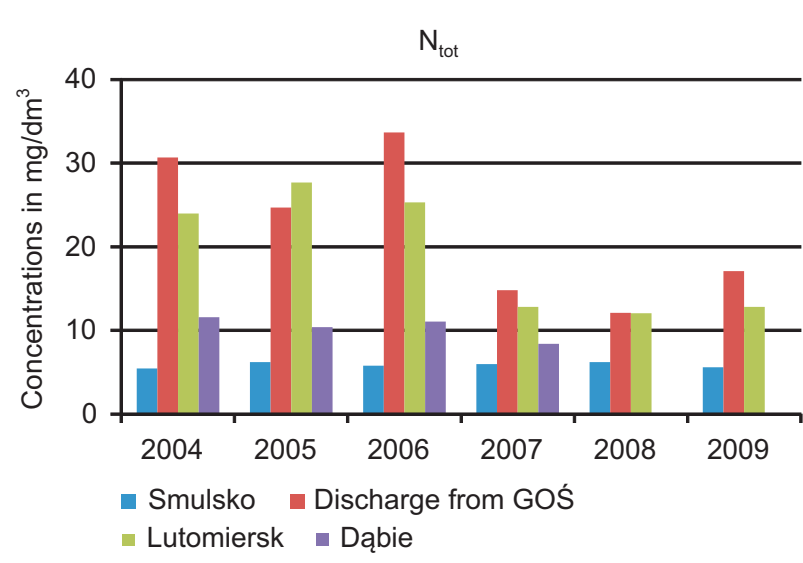

Fig. 5. $\mathrm{N}$ total concentrations expressed in $\mathrm{mg} \cdot \mathrm{dm}^{-3}$ for selected measurement points (average annual values)

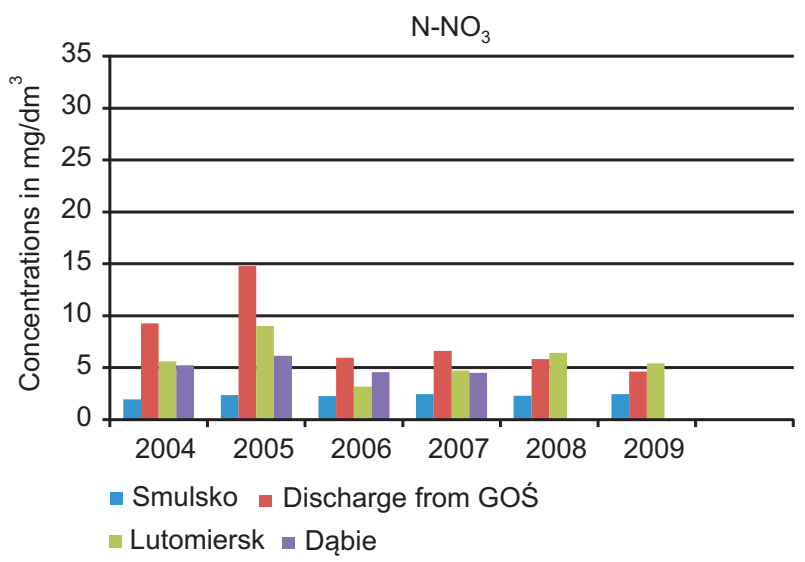

Fig. 6. $\mathrm{NO}_{3}$ concentrations expressed in $\mathrm{mg} \cdot \mathrm{dm}^{-3}$ for selected measurement points 


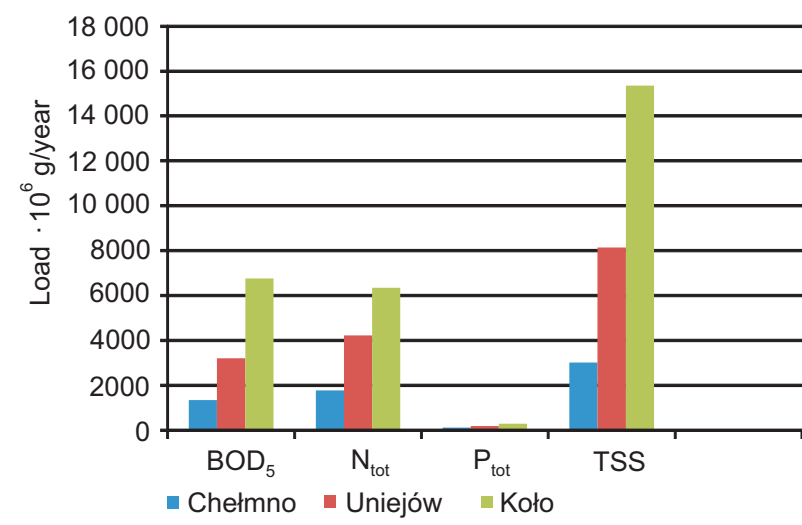

Fig. 7. Comparison of loads of selected pollution indicators at the Chełmno (Ner river), Uniejów (Warta river), and Koło (Warta river) water-gauge cross-section, in 2004-2011 (average annual values)

river), the average $\mathrm{N}_{\text {tot }}$ concentration was $9.3 \mathrm{mg} \cdot \mathrm{dm}^{-3}$ in the years 1995-2003. In the second period of 2004-2011 , this average fell to $6.44 \mathrm{mg} \cdot \mathrm{dm}^{-3}$. Considering the average flows in these years, the load was $3380 \cdot 10^{6} \mathrm{~g} /$ year and $1872 \cdot 10^{6} \mathrm{~g} /$ year, respectively. The mean value of $\mathrm{P}_{\text {tot }}$ concentrations was $1.2 \mathrm{mg} \cdot \mathrm{dm}^{-3}$ for the first period, and $0.44 \mathrm{mg} \cdot \mathrm{dm}^{-3}$ for the second period, with a load of $439 \cdot 10^{6} \mathrm{~g} /$ year and $128 \cdot 10^{6} \mathrm{~g} /$ year, respectively. The total suspension content was $28.4 \mathrm{mg} \cdot \mathrm{dm}^{-3}$ and $11.25 \mathrm{mg} \cdot \mathrm{dm}^{-3}$, respectively, giving a load of $9908 \times 10^{6} \mathrm{~g} /$ year and $3271 \cdot 10^{6} \mathrm{~g} /$ year, respectively. It follows that the load of pollutants introduced into the Warta river in the years 2004-2011 decreased: for total nitrogen by $45 \%$, for total phosphorus by $71 \%$, for total suspension by $67 \%$, and for $\mathrm{BOD}_{5}$ by $73 \%$ compared to the period of 1995-2003.

\section{CONCLUSIONS}

1. The quality of water in the Ner river clearly depended on the quality of treated wastewater, discharged from GOŚ ŁAM. P total and $\mathrm{N}$ total concentration indicators, for most measurements at the Smulsko measuring and control point (immediately before discharge of treated wastewater), were in class II and III of cleanliness. At the remaining measuring points (past the discharge from the treatment plant), these indicators were mostly

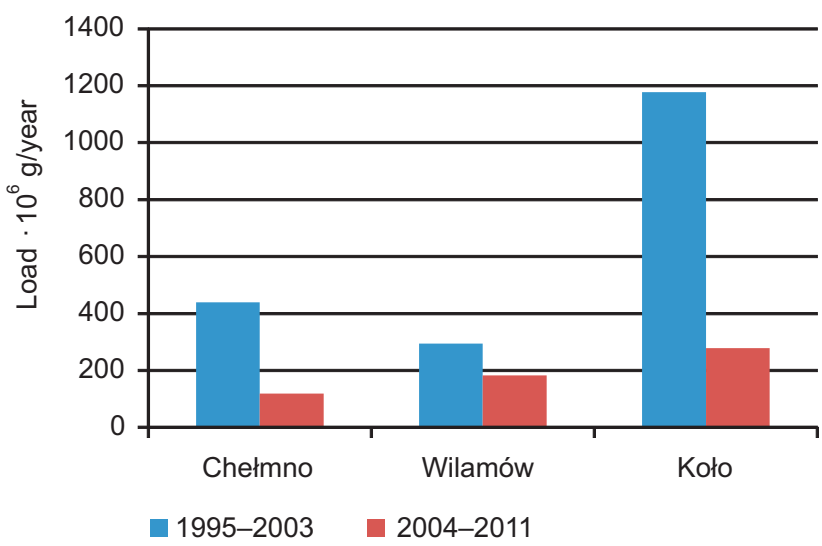

Fig. 8. Comparison of loads of $\mathrm{P}$ total on the cross-sections of Chełmno (Ner river), Wilamów (Warta river), and Koło (Warta river) in the periods 1995-2003 and 2004-2011 (average annual values)

below good. One can notice a clear improvement in the value of these indicators only since 2008 , and this coincides with the full operational efficiency of the treatment plant.

2. In the years 2004-2009, the shares of nitrate nitrogen and phosphates in total nitrogen and total phosphorus increase at the measurement points past the discharge from the treatment plant. On the one hand, this indicates better operation of the sewage treatment plant (biological decomposition), on the other hand, it also points to self-purification process of Ner river water.

3. By monitoring the values of the $\mathrm{BOD}_{5}$ indicator, in measuring points with the growing distance from the point of sewage discharge from the treatment plant, in the years 2004-2011 a clear downward trend can be observed. This demonstrates the growing potential of ecosystem self-cleaning processes. The concentration of organic compounds decreases, while there is still a threat of excessive eutrophication caused by the increasing content of nutrients.

\section{REFERENCES}

Ambrozik, K. (2010). Ichtiofauna dopływów Ner - zmiany osiem lat po uruchomieniu Grupowej Oczyszczalni Ścieków w Łodzi. Praca magisterska wykonana na Uniwersytecie Łódzkim, na Wydziale Biologii i Ochrony Środowiska w Katedrze Ekologii i Zoologii Kręgowców. 
Mosiej, J., Skrzypski, J., Suchecka, T. (2019). Impact of the Łódź Agglomeration on water quality indicators and load of pollutants in Ner and Warta rivers... Acta Sci. Pol., Formatio Circumiectus, 18 (4), 25-35. DOI: http://dx.doi.org/10.15576/ASP.FC/2019.18.4.25

Banaszkiewicz, H. (2002). Charakterystyka przyrodniczo gospodarcza zlewni rzeki Ner Katedra Ochrony i Kształtowania Środowiska AR w Poznaniu (maszynopis).

Bednarczyk, J. (1997), Wpływ miejskich i przemysłowych ścieków zrzucanych przez aglomerację łódzką na degradację środowiska naturalnego i wody w zlewni rzeki Ner oraz w rzece Warcie., Mat. Konf. „Woda jako czynnik warunkujący wielofunkcyjny i zrównoważony rozwój wsi i rolnictwa”. Falenty: Wyd. IMUZ, 139$-146$.

Ilnicki, P., Banaszkiewicz, H., Bukowski, Ł. (2003). Źródła, stężenie i ładunki azotu fosforu w wodach rzeki Ner w latach hydrologicznych 1992-1997. Sci. Pol., Form. Circ Acta. 2(1), 23-34.

Jaskuła, J., Sojka, M., Wicher-Dysarz, J., Dysarz, T. (2016). Trend of changes in physicochemical state of the river Ner. Journal of Ecological Engineering, 17(5), 27-34. DOI: //doi.org/10.12911/22998993/64447

Lik, J., Sołtuniak, J. (2012). Wykorzystywanie zasobów wodnych województwa łódzkiego na cele energetyki i towarzyszącej jej turystyki. Łódź: Wyd. PAN.

Mosiej, J., Multan, H. (1998). Grasslands as a natural filter for municipal waste water and biogens. In: Pertu, K., Obarska-Pempkowiak, H. (Eds). Sewage treatment by means of pine, willow, reed and grass vegetation filters. Agric. Univ. Uppsala. 59-62.

Mosiej, J., Komorowski, H., Karczmarczyk, A. (1997). Factors affecting water quality in degraded sewage receivers: case study of the phosphorus dynamics in the Ner River. Journal of Water and Land Development, 11, $103-116$.

Mosiej, J., Komorowski, H., Karczmarczyk, A., Suska, A. (2007). Wpływ zanieczyszczeń odprowadzanych z aglomeracji łódzkiej na jakość wody w rzekach Ner i Warta. Sci. Pol., Form. Circ Acta., 6 (2), 19-30.
Mosiej J., Suchecka T. (2017). The role of irrigation in river valleys to develop water quality, production of biomass and sustainable rural development - case study. Proceedings of the $8^{\text {th }}$ International Scientific Conference Rural Development, 692-697.

Multan, H. (1993). „Efekty i ograniczenia nawodnień wodami ściekowymi”. „Współczesne problemy melioracji”. Red. Cz. Somorowski SGGW, 223-233.

Multan, H. (1996). „Zastosowanie systemów nawadniających do redukcji zanieczyszczeń ze ścieków”, „Ochrona i zrównoważony rozwój środowiska wiejskiego", Red. Brandyk T., Hewelke P., Wyd. SGGW, 268-289.

Penczak, T., Kruk A., Grabowska J., Śliwińska A., Koszaliński H., Zięba G., Tybulczyk S., Galicka W., Marszał L. (2010). Wpływ stopniowej poprawy jakości wody w rzece Ner na regenerację ichtiofauny. Roczniki naukowe PZW, 23, 97-117.

Skrzypski, J. (2013). Wpływ oczyszczalni ścieków w Łodzi na kształtowanie wskaźników jakości wody rzek Ner i Warta w latach 2004-2011. Praca dyplomowa magisterska wykonana w Katedrze Kształtowania Środowiska SGGW.

Somorowski, Cz., Multan, H., Mosiej, J., Szatyłowicz J. (1991). Wpływ nawodnień ściekami na plonowanie i elementy bilansu wodnego gleby użytków zielonych w dolinie rzeki Ner. ZN AR Kraków, 249, 81-101.

Śliwińska, A. (2007). Wpływ sukcesywnej poprawy jakości wody w rzece Ner na regenerację ichtiofauny. Praca magisterska wykonana na Uniwersytecie Łódzkim, na Wydziale Biologii i Ochrony Środowiska w Katedrze Ekologii i Zoologii Kręgowców

Zamojski, M. (1995). Ocena stanu i funkcjonowania urządzeń melioracyjnych na obiektach w dolinie rzeki Ner. Praca magisterska wykonana w Szkole Głównej Gospodarstwa Wiejskiego - AR w Warszawie na Wydziale Melioracji i Inżynierii Środowiska.

\section{WPŁYW AGLOMERACJI ŁÓDZKIEJ NA KSZTAŁTOWANIE WSKAŹNIKÓW JAKOŚCI WODY I ŁADUNKI ZANIECZYSZCZEŃ RZEK NER I WARTA W LATACH 1995-2011}

\section{ABSTRAKT}

\section{Cel pracy}

Celem pracy jest ocena wpływu ograniczenia zrzutu zanieczyszczeń po modernizacji oczyszczalni ścieków ŁAM na ładunki zanieczyszczeń w środkowym i dolnym biegu rzeki Ner. W tym celu porównano stężenia i ładunki zanieczyszczeń w dwóch okresach 1995-2003 i 2004-2011. 


\section{Materiak i metody}

Materiał źródłowy stanowiły informacje uzyskane z oczyszczalni ścieków dotyczące podstawowych wskaźników zanieczyszczeń zrzucanych do rzeki oraz przepływy i stężenia zanieczyszczeń w przekrojach wodowskazowych Ner i Warty.

Jako wskaźnik przyjęto udział wprowadzanych zanieczyszczeń do Warty przez rzekę Ner w ładunku zanieczyszczeń rzeki Warty w pierwszym przekroju pomiarowym na Warcie poniżej ujścia rzeki Ner.

\section{Wyniki i wnioski}

W okresie 1995-2003 średnio roczny przepływ rzeki Ner wynosił ok. 10\% średniego rocznego przepływu rzeki Warty w punkcie poniżej ujścia rzeki Ner (ppk Koło) a w okresie 2004-2011 r. na podobnym poziomie $13,8 \%$ natomiast ładunek zanieczyszczeń wnoszonych przez rzekę Ner stanowił w pierwszym okresie średnio $27 \%$ azotu, $37 \%$ fosforu ogólnego, 39\% BZT $_{5}$ i $28 \%$ zawiesiny ogólnej w wodzie Warty a w drugim okresie analogicznie 27,9\%, 42,6\%, 19,8\% i 19,6\%. Tak jak w pierwszym okresie stwierdzono brak odpowiedniej reakcji na zmniejszenie się ładunku fosforu odprowadzanego przez Grupową Oczyszczalnię Ścieków (GOŚ) na jego zawartość w wodach Ner, a wzrost tego wskaźnika, natomiast stwierdzono obniżenie wskaźnika BZT5 $_{5}$ i zawiesiny ogólnej. W warunkach niskiego stężenia fosforu w odprowadzanych ściekach (poniżej $4 \mathrm{~g} \cdot \mathrm{m}^{-3}$ ) maksymalnie w $2007 \mathrm{r}$. wyniósł $1,23 \mathrm{~g} \cdot \mathrm{m}^{-3}$ odprowadzanych z oczyszczalni a przy ujściu rzeki Ner nie zaobserwowano w tym czasie polepszenia jakości wody w profilu Chełmno (średnioroczne stężenie $0,78 \mathrm{~g} \cdot \mathrm{m}^{-3}$ ).

Słowa kluczowe: jakość wody, oczyszczanie ścieków, rzeka Ner 